\title{
Teachers' Computer Capacity in Public Primary Schools in Homa Bay County, Kenya: The Case of the Digital Literacy Programme
}

\author{
Ouma Omito, \\ School of Education, Umma University, Kajiado, Kenya \\ Dr. Jane Kembo, \\ School of Education, Rongo University, Rongo, Kenya \\ Dr. Mildred Ayere, \\ Maseno University, Maseno, Kenya \\ Dr. Ali Adan Ali, \\ Research, Innovation and Outreach, Umma University, Kajiado, Kenya
}

Doi:10.19044/esj.2019.v15n19p301 URL:http://dx.doi.org/10.19044/esj.2019.v15n19p301

\begin{abstract}
Kenyan public primary schools are rapidly adopting digital technology in teaching and learning. The purpose of this study was to establish teachers' computer skills as groundwork towards the integration of laptop computers in public primary schools in Homa Bay County, Kenya. The study was based on one objective: to investigate the teachers' computer skills that were necessary for the Digital Literacy Programme (DLP) in Homa Bay County. A crosssectional survey was adopted as the research design whereby both quantitative and qualitative research data were collected and used for the study. The study population comprised of 6,529 teachers and 845 head teachers in public primary schools in Homa Bay County. A sample size of 362 teachers and 85 head teachers were used for the study. Data were collected using questionnaires and interview schedules. Quantitative data were analyzed using descriptive statistics. The results from the interviews were recorded, transcribed, organized into major themes and reported. The findings showed that $199(56.4 \%)$ sample teachers had attended general computer literacy courses at various institutions of learning. The study also showed that 109 (30.9\%) of the sampled teachers had been trained by the government on DLP. However, when the teachers' computer skills were rated on a 5-point Likert scale, they were found to be low (2.76). In addition, 35 (44.3\%) of the sampled schools had no teacher trained in computer skills by their colleagues as was expected. The study concluded that sample teachers had a good starting point
\end{abstract}


for computer skills training which only needed to be strengthened by the government.

Keywords: Digital Literacy Programme, Computer skills, digital devices, laptop computer, teachers, schools

\section{Introduction}

\section{Background of the Study}

Computer usage for teaching and learning in schools should not be considered as a luxury in the present world. This is because the use of technology in education is a part of what today's generation utilizes in meeting their learning needs from time to time. Since the demand for the use of technology is on the rise, the growing numbers of different technologies in the field of specifically education are also increasing. Laptop computers and other similar technologies such as tablets have become highly popular versions of desktop computers with the full functionality of desktop computing and the portability which allows users to carry them every time anywhere (Mathevula \& Uwizeyimana, 2014). The development of ICT education, especially the use of computers to teach and learn started, on a low pace but was strengthened by the Nepad e-school program for Africa that was initiated by the support of the e-commission to facilitate the integration of ICT in Africa. The Nepad eschool was specifically meant to empower teachers' computer skills for teaching and learning. In this program, six secondary schools in Kenya benefited. They included Menengai, Chavakali, Maranda, Isiolo, Mumbi, and Wajir Secondary Schools (Nyagowa, Ocholla \& Mutula, 2012).

However, there was no evidence to show that primary schools and their teachers were catered for in this ICT integration program. In addition, before the launch of the Digital Literacy Programme (DLP) in Kenya, many primary schools suffered from inconsistencies and biases in the distribution of computers to schools by the government and other stakeholders in education. The data from the Ministry of Education in Kenya showed that when primary schools were compared to tertiary institutions, primary schools had the highest learner to computer ratio, that was, 250 students against 1 computer (Kenya. MoE, 2006; UNESCO Institute for Statistics, 2012). The aforementioned learner to computer ratio was found to be far much below the world ratio which, the Ministry of Education in Kenya recommended to be 15 students to 1 computer (Kenya. MoE, 2006).

Many public primary schools, especially in the rural areas of Kenya before the launch of DLP, had no computers in schools at all. To support the latter, Mingaine (2013) conducted a research in many schools in Kenya and established that even the few schools that had computers were not effectively adopting and using them to support learning, teaching, and management as 
was intended because of lack of computing resources such as electricity and teachers' computer skills.

The Government of the Republic of Kenya (Republic of Kenya, 2015) advocated for the laptop computer to primary schools in Kenya, which were meant to bridge the digital gap.The One Laptop Computer Per Child (OLPC) program was then slated to kick off in January 2014 (Sharples \& Moldéus, 2014). However, in May 2016 during the rollout, the policy shifted from laptop computers to tablets due to cost implications (Wanzala \& Nyamai, 2018). However, the government maintained laptop computers for DLP as Teacher Digital Devices (TDD) while tablets remained Learner Digital Devices (LDD). The introduction of laptop computers to primary schools was also in line with the recommendations of the Kenyan ICT policy framework that advocated for full integration of ICT in all educational institutions in Kenya by the use of appropriate digital equipment (Kenya. MoE, 2006).

Based on the government reports, as of June 2015, Kenya had 22, 175 public primary schools and it was the intention of the Government of the Republic of Kenya to roll out ICT integration program in class one in every public primary school by providing each child with a laptop computer (Republic of Kenya, 2015). To make evident the government's commitment on this, 62,500 teachers completed training by August 2015. Each school was required to sponsor two teachers and a head teacher to attend the 5-day DLP training, after which the trained teachers were expected to return to their respective schools to train their colleagues who did not attend the Digital Literacy Program (DLP) training (Republic of Kenya, 2015).

The study was meant to establish the teachers' level of computer training for utilization of ICTs in the 22,175 public primary schools in Kenya that were using hard copy textbooks and chalk walls for teaching and learning at the time of the study. However, the study noted that the government did not provide each school with digital devices for practice and training as was required. The study, therefore, was interested in establishing the computer skills of teachers who were expected to lead the learners in integrating DLP devices in public primary schools in Homa Bay County.

\section{Statement of the Problem}

Based on the information given in the background of this study, it is evident the Government of Kenya was committed to the integration of technology in public primary schools in Kenya and that an estimated 62,500 teachers in public primary schools received training for 5 days for DLP in public primary schools. Each public primary school was also expected to avail two teachers and a head teacher for the DLP training. The DLP-trained teachers in each school were expected to train their colleagues who did not attend the DLP training. The reviewed literature of this study noted inadequate 
teacher training on computer skills, teachers' fear to handle technology because of inadequate computer skills and lack of computers in schools for regular practice. Therefore, in line with the DLP training for teachers, the study raised two questions that needed answers in this study: Did teachers have adequate computer skills that could enable them to integrate laptop computers in teaching and learning in their respective schools? Did the DLP trained teachers train their colleagues as was expected?

\section{Purpose of the Study}

The purpose of this study was to establish teachers' computer skills as groundwork towards the integration of laptop computers in public primary schools in Homa Bay County, Kenya.

\section{Literature Review}

The philosophy behind projects such as One Laptop Per Child (OLPC) was to make computers available to children both at home and school so that the digital gap could be bridged (Meenakshi, 2013). However, learning should be directed either face-to-face or online. Well-trained teachers who are equipped with ICT skills should have the responsibility of helping students develop ICT skills in the classroom (European Commission, 2011). This is because teachers' roles are fast changing as agents mandated with the responsibility of bridging the digital gap in schools to facilitators of learning. Successful integration of ICT into the Kenyan education, therefore, depended largely on the teachers' computer skills and ability to handle online tools (Hernandez, 2017).

\section{Teachers' Computer Capacity in Africa and Other Parts of the World}

In Africa, the introduction of computers in primary and secondary schools is a recent phenomenon that needed a capacity building (Mndzebele, 2013). For teachers in schools to cope with the growing trends in education, adequate training in ICT was inevitable. This called for policies that promoted broad access to skills and competencies, and especially ICT literacy among teachers. In support, Khan, Hasan, and Clement (2012) noted that within a few years, Information and Communication Technology (ICT) had turned out to be an effective educational technology, which promoted dramatic changes in the teaching and learning processes. The teachers' training and role in technology-rich classrooms were more demanding than ever.

Mndzebele (2013) also added that technology integration requires that teachers understand the technology tools themselves and know which tools would make learning easier for the students. Teachers, therefore, needed to have basic technology skills and knowledge on how to use technology for 
hardware and software for teaching. Otherwise, teachers were likely to meet problems in utilizing the technology effectively in the classroom.

The need for prior ICT training for teachers before the integration of ICT into schools was observed to be necessary in teaching and learning (Tilya, 2007). He argued that ICT literacy provides equal access to information and reduces the information gap. Skills such as keyboard use, searching for information, evaluation skills, word-processing, and presentation skills are vital in helping schools to integrate ICT in its operational procedures and even in specific subject areas. Greece, for example, offered both initial and inservice training for primary school teachers at three levels. The first level was training in basic computer skills. The second level involved incorporation of computer and ICT tools into the educational process, and lastly, trainees familiarized themselves with the educational software (European Commission, 2001, p.27). Each level in one way or the other aimed at enhancing the other. The study observed that the last level should be extended to include practical use of ICTs in Kenyan schools and not only familiarizing learners with educational software.

This is because Tilya (2007) observed that teachers from different schools who had gone through the training process and had hands-on ICT experience helped their schools to understand the contribution of ICT to learning and could use different learning approaches. Therefore, training and providing facilitators of DLP with the appropriate knowledge and skills could facilitate the integration of laptop computers in Kenyan schools.

In Kenya, the Ministry of Education facilitated the use of ICT as a tool for education in all institutions of learning in Kenya by giving a road map on the integration process (Kenya. MoE, 2006, p.9). However, the Kenyan DLP training was a single package computer training that lasted for 5 days and covered all the three levels of teacher training as opposed to what happened in Greece.

To motivate teachers and make training more meaningful, Sweden in its initiative to train 700, 000 teachers in both primary and secondary schools, offered all the teachers free computers to practice with when the training was over. The same was also witnessed in the United Kingdom where a number of schemes were introduced to offer teachers subsidized or free computers for practice after the training (European Commission, 2001, p.27). The practice was slightly different in Kenya because their DLP trained teachers were not offered computers for further practice after the training (Sharples \& Moldéus, 2014).

In South Africa, the Department of Education acknowledged that many teachers grew up in an environment that had less or no electronic technology available and thus found working with computers more difficult compared to the ICT literacy levels of their learners (South Africa. DoE, 2003, p.30). To 
remedy this, the department through the Standards for Professional Competency in ICT utilization proposed that computer capacity-building process for active teachers should consider the following levels.

i. Entry, computer literate teachers who are able to use computers and teach learners to use computers;

ii. Adoption, Teachers who are able to use various technologies, including the computer, to support traditional management, administration, teaching, and learning;

iii. Adaptation, Teachers who can use computers to enrich the curriculum and utilize integrated systems for management and administration;

iv. Appropriation, Teachers who can integrate computers into teaching and learning activities, and use integrated systems for management and administration within a community context;

v. Innovation, Teachers who are well prepared to develop entirely new learning environments that use computers as a flexible tool in such a way that learning becomes collaborative and interactive. Technology is integrated as a flexible tool for whole development of the school.

On the contrary, DLP in Kenya had no entry level for training. The requirement for that training was that some two teachers and a head teacher had to be sponsored by a school to participate in a 5-day teacher training (Republic of Kenya, 2015). However, when compared to South Africa's model, the DLP training model assumed that all teachers who attended the training had the same level of computer skills and did not cater to individual competencies.

In a study done through census drawn on 700 teachers from twentyfive purposefully selected private secondary schools in Ibadan, Oyo state, Nigeria, technical support in schools and teachers' lack of expertise in using computers were indicated as being the prominent factors hindering teachers' readiness and confidence in using computers during lessons. Even though, the results indicated that teachers perceived computers as being easier and very useful in teaching and learning, it was recommended that teacher training and professional development-oriented policies should support computer-related teaching models that encourage both students and teachers to play active roles in teaching/learning activities (Tella, Toyobo, Adika, \& Adeyinka, 2007).

In Tanzania, Non-Governmental Organizations (NGOs) such as The Bright Education Trust Fund participated actively in the development of teacher capacity by teaching them how to use computers to improve both classroom teaching and administrative procedures in their respective schools. To achieve this, the NGOs opted to train teams of teachers within a school because it believed that teams of teachers could introduce revolutionary ideas within a school more effectively than individual teachers (Tilya, 2007). 


\section{Teachers' Computer Capacity in Kenya}

According to Hennessy, Harrison, Ang'odi, Nemalefe, Naseem, and Wamakote (2010), large-scale capacity building workshops for teachers was the way forward towards full integration of computers in schools in Kenya. They observed that teacher training should be built on strong computer structures that support ongoing professional development for teachers. The program, they said, ought to be consistent with the workshops for lecturers and pre-service teachers at teacher training colleges.

Some institutions in Kenya had used ICT for teaching and learning. A study was conducted in Kajiado County in one of the secondary schools with a population of 535 students and 28 teachers. The sample size of 30 students and 18 teachers. Survey design with questionnaires was used to collect data alongside observation of teachers' lessons. The findings revealed that $77 \%$ of the teachers who were the majority could use computers to teach, research, plan, and keep records (Kisirkoi, 2015).

In primary schools in Kenya, Sharples and Moldéus (2014) conducted a study on perception of schools in readiness for adoption of laptop computers in seven out of the more than twenty thousand, which were set to receive laptop computers in Kenya by 2014 . The study adopted a multi-site case study design. This study consists of collecting both quantitative and qualitative data. The findings revealed that $60 \%$ of the teachers lacked adequate ICT training. Teachers also feared that pupils were better equipped with ICT skills than they were and could easily challenge their authority in class.

DLP lessons in Kenyan public primary schools were set to meet lesson delivery challenges during teaching and learning if teachers failed to gain and put into use the right computer skills. This is because some teachers spent more than 20 minutes in arranging the class while others experienced failure of devices due to power. These difficulties gave the teachers a hard time in putting DLP classes in order before the lessons would continue (Wanzala \& Nyamai, 2018).

In summary, the literature reviewed strongly advocated the need for a pedagogical shift in the field of education. However, complete migration to the digital platform was still staggering in a number of developing countries in Africa such as Kenya. It is worth noting that inadequate teacher training in computer applications attributed largely to failures in the launch of ICTs at many schools in developing countries.

\section{Research Methodology Research Design}

The research design for this study was the concurrent triangulation cross-sectional survey whereby the researcher collected both quantitative and qualitative data concurrently then compared to see if there was a point of 
convergence or difference (Creswell, 2011, p.213). The survey design used both questionnaires and interview schedules to collect and generalize data from a sample to a population (Creswell, 2011, p.12). The research methodology section intended to answer study one objective: to investigate the teachers' computer skills that were necessary for the Digital Literacy Programme (DLP) in Homa Bay County.

Table 1. Expected results from the study objective

\begin{tabular}{|c|c|c|c|}
\hline The instrument used & Respondent & Item & Expected results \\
\hline Questionnaire & Teachers & $\begin{array}{l}\text { Have you ever } \\
\text { attended any } \\
\text { computer training? }\end{array}$ & $\begin{array}{l}\text { Attendance or no } \\
\text { attendance of } \\
\text { different institutions } \\
\text { for computer } \\
\text { training }\end{array}$ \\
\hline Questionnaire & Teachers & $\begin{array}{l}\text { What is the } \\
\text { teachers' general } \\
\text { computer capacity? }\end{array}$ & $\begin{array}{l}\text { Low or moderate or } \\
\text { high-rating on a } 5- \\
\text { point Likert scale }\end{array}$ \\
\hline Questionnaires & Head teachers & $\begin{array}{l}\text { Did DLP-trained } \\
\text { teachers train their } \\
\text { colleagues on } \\
\text { computer skill? }\end{array}$ & $\begin{array}{l}\text { Teachers were } \\
\text { trained or weren't } \\
\text { trained by their } \\
\text { colleague(s) }\end{array}$ \\
\hline Interview schedule & Teachers & $\begin{array}{l}\text { Are teachers skilled } \\
\text { enough to teach } \\
\text { using laptop } \\
\text { computers? }\end{array}$ & $\begin{array}{l}\text { Yes/No. If no, } \\
\text { sufficient reason(s) } \\
\text { given }\end{array}$ \\
\hline
\end{tabular}

\section{The Population of the Study}

The population of the study constituted of 6,529 teachers and 845 head teachers in public primary schools in Homa Bay County. The population was then stratified into six sub-counties: Mbita, Homa Bay, Rachuonyo North, Rachuonyo South, Suba, and Ndhiwa as shown in Table 2. The teachers who were interviewed also formed part of the 6,529 teachers. Teachers were selected as participants in this research by their virtue of being the curriculum implementers and instructors at the primary schools level. To estimate the population of all teachers and public primary schools head teachers in the county of Homa Bay, the researcher analyzed the official government documents from the county education offices. One head teacher headed each school.

Teachers were the ones to engage learners directly in teaching and learning using laptop computers in classrooms. To establish the number of teachers who attended the DLP training and the number of teachers trained by their colleagues per sample school, the study used the sampled head teachers as heads of institutions with detailed information of individual teachers in their schools. The teachers not trained under DLP were also active in teaching service and were not exempted from the integration of ICT or laptop 
computers in schools. These teachers were also part of the 6, 529 teachers that constituted the population of this study.

\section{Study Sample}

In this study a total of 362 teachers, 85 head teachers, and 12 teachers participated. To ensure equal distribution of samples in all parts of Homa County, stratified sampling technique based on the population strength of teachers and head teachers in each sub-county was used such that the subcounty with the highest number of teachers had a higher representation in the final sample for each sub-county as shown in Table 2 . Teachers in any sampled school were randomly selected to participate in the study provided they were identified by the head of the institution as a qualified and registered teacher in the school.

Table 2. Sample size summary

\begin{tabular}{llll}
\hline Sub-county & $\begin{array}{l}\text { Teachers } \\
\mathrm{n}\end{array}$ & $\begin{array}{l}\text { Head } \\
\text { teachers } \\
\mathrm{n}\end{array}$ & $\begin{array}{l}\text { Teachers } \\
\text { interviewed } \\
\mathrm{n}\end{array}$ \\
\hline Homa Bay & 82 & 17 & 2 \\
R. North & 65 & 17 & 2 \\
R. South & 73 & 16 & 2 \\
Suba & 35 & 9 & 2 \\
Mbita & 40 & 11 & 2 \\
Ndhiwa & 67 & 15 & 2 \\
Total & 362 & 85 & 12 \\
$(\%$ of N) & $(5.5 \%)$ & $(10.0 \%)$ & $(0.2 \%)$ \\
\hline
\end{tabular}

\section{Sampling Procedure for Teachers}

The sample size for teachers was determined using the confidence level approach (Kothari \& Garg, 2014) where $N$ is the population $(6,529)$; $n$ is the required sample size; $\boldsymbol{p}$ and $\boldsymbol{q}$ are the proportions of the targeted population $(0.5) ; \boldsymbol{E}$ is the accuracy of sample proportions $(0.05) ; \boldsymbol{Z}$ is the standard deviation at a given confidence level of $95 \%$ (1.96). Based on the available information, the sample size was determined. Therefore:

$$
\begin{aligned}
& \mathrm{n}=\quad \mathrm{N}^{2} \mathrm{Pq} \\
& \underline{\left(\mathrm{E}^{2}(\mathrm{~N}-1)+\mathrm{Z}^{2} \mathrm{Pq}\right)} \\
& \mathrm{n}=\quad 6529 * 1.96^{2}(0.5 * 0.5) \\
& \left(\left(0.05^{2}(6529-1)+1.96^{2 * 0.5 * 0.5)}\right)=362.8650\right.
\end{aligned}
$$

Based on the strength of representation, the sampled 362 teachers were stratified in six sub-counties of Homa Bay County as shown in Table 2. Teachers' selection for the study for a particular sub-county was confined to sampled schools in each sub-county of the study. As shown in Table 2, the number of teachers in each sub-county was spread proportionally to the 
number of sampled schools in that particular sub-county whereby each sampled school had equal slots of sampled teachers.

\section{Sampling Procedure for Schools and Head Teachers}

There were 845 public primary schools in Homa Bay County. A head teacher headed each school. The researcher sampled 85 out of 845 head teachers which were $10 \%$ of the representation of the population of schools in Homa Bay County. Since the number of head teachers was equivalent to the number of public primary schools, the 85 sampled head teachers assisted the study in establishing the number of teachers who were DLP-trained in the 85 sampled schools they were heading. Like the teachers, the head teachers were also stratified into six sub-counties of Homa Bay based on the population strength of head teachers in each sub-county of Homa Bay. That is the population of head teachers in a sub-county out of the total number of head teachers (845) multiplied by the sample size ( 85 head teachers).

\section{Sampling Procedure for Interview Schedules}

Semi-structured interviews were also conducted for sampled teachers in Homa Bay County. The study stratified Homa Bay County into six subcounties of Homa Bay, Rachuonyo North, Rachuonyo South, Mbita, Suba, and Ndhiwa. The interviewed teachers were picked from the population of 6,529 teachers that were used for this study. In each sub-county, two teachers were randomly picked for interview, hence, a total of twelve teachers were interviewed. The study ensured that the identities of those who were interviewed were noted so that they did not take part in the filling of questionnaires. The interviews corroborated the data from questionnaires.

\section{Research Instruments}

The study used questionnaires and interview schedules for data collection. Questionnaires were used to collect data from sampled teachers and head teachers. Interview schedules collected data from sampled teachers only.

\section{Questionnaires for Teachers}

The 362 teachers' questionnaires were used. The first part of the teachers' questionnaire tested on teachers' attendance in computer training. Such questions included: 'Have you ever attended any computer training? If yes, for how long (period)?' The second section of the teacher questionnaire tested on teachers' computer skills using a five-point Likert scale: Not at all = 1 , Not so well $=2$, Okay $=3$, Well $=4$, and Very well $=5$. Necessary computer skills such as teachers' ability to rotate an image, create documents using Microsoft Word and Excel, draw and label diagrams using a computer, use of PowerPoint to present lessons, save contents to an external disk (flash disk), animate using a computer, access the internet using Mozilla or Internet 
Explorer, send and receive e-mails, and finally print a document were tested in the second part. Ethical issues such as confidentiality and anonymity of the respondents were observed during and after data collection. Questionnaires had no names and were coded for easy entry of data.

\section{Questionnaires for Head Teachers}

The 85 questionnaires for head teachers were designed to generate information on teachers in two ways. The first part required head teachers to establish whether their schools sponsored some teachers for DLP training. The second section required the head teachers to mention the number of teachers who were trained by their colleagues in their respective schools after the DLP training. Questionnaires for head teachers helped the study to confirm the government's position that teachers who attended DLP training trained their colleagues in their schools.

\section{Interview Schedules}

The interview schedule was designed to generate data to strengthen the outcome of data generated by the use of questionnaires. Sampled primary school teachers in Homa Bay County were the respondents for the interview schedules. Teachers were interviewed because they understood the nature of schools and the learning process in their respective schools. The researcher conducted the interviews and ensured that ethical issues such as privacy and confidentiality of the respondents were strictly observed. Interview questions were centered on teachers' competence in handling DLP devices.

\section{Pilot Study}

The pilot study for this research used $10 \%$ of the sample size for respondents to questionnaires (Connelly, 2008). Hence, 36 teachers and 8 head teachers were piloted randomly in the six sub-counties using questionnaires. One teacher was randomly picked from any of the six sub-counties for piloting using an interview schedule. The study ensured that those who had participated in piloting were not picked for the main study.

\section{Instrument Validity and Reliability}

Both content and construct validity were picked for use in this study. Two experts in educational technology, who were $\mathrm{PhD}$ holders, were engaged in the validation of the research instruments. Before data collection, they compared the objectives and the questionnaire items. The format, language used, and framing of questionnaire items was checked. Content validity assisted during the preparation of the research instruments to ensure that the content of the instruments was not irrelevant but only reflected the objectives of the study. Construct validity was used by the study more particularly after 
data collection to see any points of convergence or divergence of data from questionnaires and interview schedules (Creswell, 2012). It was based on the results and comments from the pilot study. Some questionnaire items such as demographic data were necessary for general information but were not necessary for data analysis. After the pilot study, the study instruments data were found to be valid and were used for data analysis.

For reliability, internal consistency reliability was used. Internal consistency reliability assesses the consistency of results across items within a test. Cronbach's alpha $(\alpha)$, which is usually interpreted as the mean of all possible split-half coefficients, was used. Cronbach's alpha $(\alpha)$ uses Statistical Package for Social Sciences (SPSS) to work out all the means of possible splithalves of items in questionnaires. The questionnaire items obtained a Cronbach's alpha of 0.962 for teachers and 0.95 for head teachers' questionnaires. For the interview schedules, the questioning and recording were improved. The responses that resulted from unclear questioning also helped the researcher in reframing and refining interview questions.

\section{Data Collection Procedures}

Before data collection, National Commission for Science and Technology Innovation (NACOSTI) issued a research authorization permit. The main research instruments used for data collection were questionnaires and interview schedules. Data collection for both qualitative and quantitative data collection instruments was done concurrently in a time span of one month. Interviews were to help in data triangulation and resolve unclear information on the area of research that could not be gleaned from the questionnaires schedules, thus filling in the gaps and strengthening the information in the study. Separate questionnaires were administered to the sampled public primary school teachers and head teachers in their respective sampled schools in line with the data collection schedules that expected research activities to be conducted in schools between 8.00 am and $5.00 \mathrm{pm}$ on school working days. Upon arrival in a sample school, the researcher or research assistants received permission from the head of the institution. The head of the sampled institution assisted the researcher in identifying randomly the teachers who participated in the study. The filling of questionnaires took less than 10 minutes while the interview sessions lasted for no more than 10 minutes. The researcher arranged for the interviews at the interviewee's convenience. Two teachers were interviewed in the CSO's office, three teachers in their homes while the remaining seven teachers were interviewed at their stations of work. The researcher did all the recordings and transcriptions of data collected. The interview period took between 7 and 10 minutes.

The collected data from questionnaires were coded for data analysis using SPSS while the data from interview schedules were recorded, 
transcribed, organized into major themes and reported.

\section{Data analysis techniques}

The data were analyzed both qualitatively and quantitatively. Descriptive statistics formed the analysis of the quantitative data via percentages, mean scores, and frequencies. Tables, bar charts, and circle graph showed the survey data. The Statistical Package for Social Sciences (SPSS) version 20.0 analyzed quantitative data. The average mean of scores of data on a five-point Likert scale $(\mathrm{SD}=1, \mathrm{D}=2, \mathrm{U}=3, \mathrm{~A}=4, \mathrm{SA}=5$; Not at all = 1 , Not so well $=2$, Okay $=3$, well $=4$, very well $=5$ ) was used and the average mean compared to the e-learning readiness level of 3.41 (Aydin \& Tasci, 2005). Figure 1 shows the interpretation of these results.

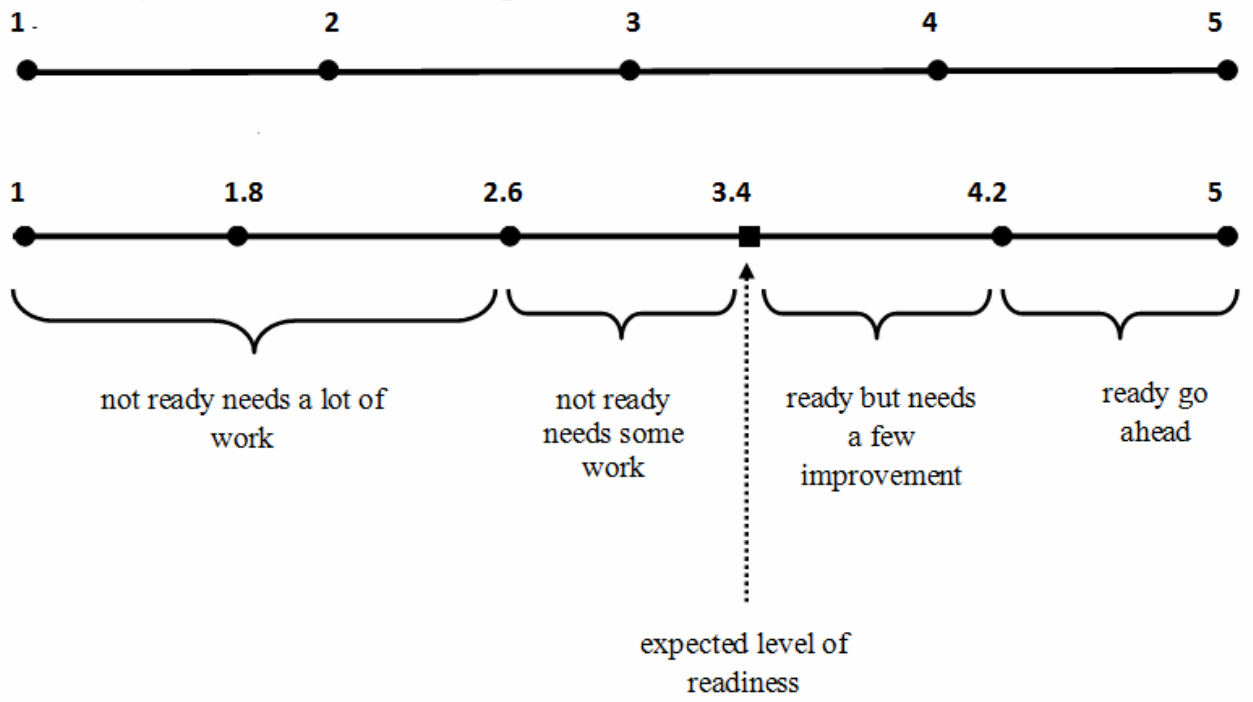

Figure 1. E-learning readiness scale

Source: Aydin and Tasci (2005).

Based on Aydin and Tasci (2005), any findings whose mean average was above 3.41 showed adequate readiness for handling laptop computers. On the other hand, findings whose average mean was below 3.41 reflected some degree of inadequacy in teachers' computer skills that were necessary for teaching using laptop computers. A recording of interviews followed by transcriptions did qualitative data analysis The already transcribed data were then coded and grouped into major themes that were converted into percentages and reported.

\section{Response Rate}

The response rate for public primary school teachers was $97.5 \%$. These response rates were adequate and reliable for data analysis. Seventy-nine out 
of 85 head teachers responded by filling in questionnaires and this represented $92.9 \%$ of the sample. The response rate for teachers interviewed was $100 \%$ as shown in Table 3. In support, Fraenkel and Wallen (2009) say that the tenet of good survey research is the high response rate.

Table 3. Response rates

\begin{tabular}{llll}
\hline Research Instrument & $\begin{array}{l}\text { Sample } \\
\text { size } \\
\text { (n) }\end{array}$ & $\begin{array}{l}\text { Response } \\
\text { rate }\end{array}$ & Percentage \\
\hline Teachers Questionnaires & 362 & 353 & 97.5 \\
Head teachers questionnaires & 85 & 79 & 92.4 \\
Interview Schedules & 12 & 12 & 100.0 \\
\hline
\end{tabular}

Presentation of Research Findings, Discussions, Conclusions, and Recommendation

This section has presented the findings in summary and in each category of the respondents based on the research questions asked. The objective of this study is to investigate the teachers' computer skills that were necessary for the Digital Literacy Programme (DLP) in Homa Bay County.

a) Teachers' prior computer literacy before DLP

The research findings showed that majority of the sample teachers, 199 (56.4\%), had undergone some computer training at different institutions while $153(43.3 \%)$ sample teachers, who were the minority, did not have any prior computer training. One $(0.3 \%)$ respondent did not respond to this question as shown in Figure 2. 


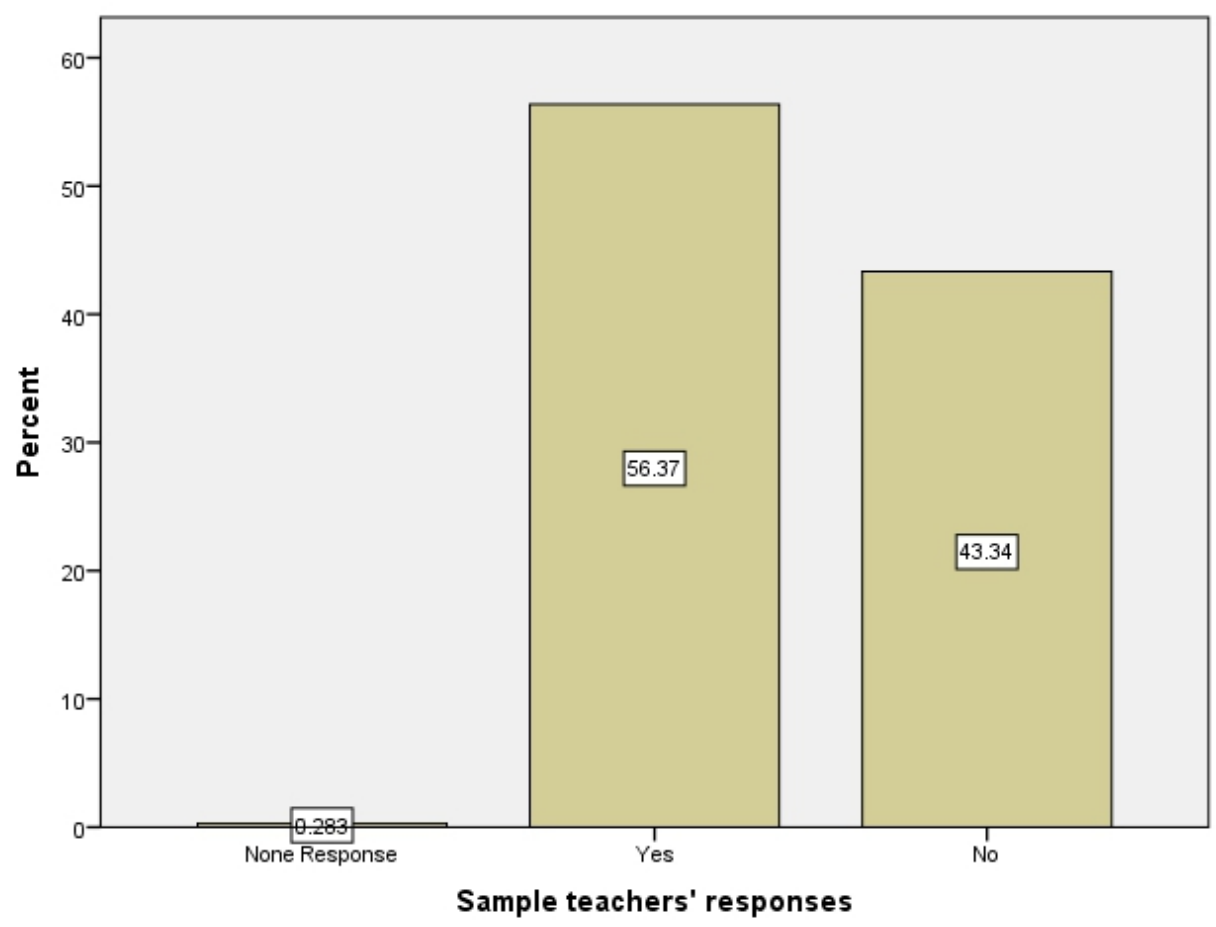

Figure 2. Teachers' prior computer literacy before DLP

\section{b) Teacher computer skills necessary for DLP}

The study generated data on teachers' computer skills to rotate an image, create documents using Microsoft Word and Excel, draw and label diagrams using a computer, use of PowerPoint to present lessons, save contents to an external disk (flash disk), animate using a computer, access the internet using Mozilla or Internet Explorer, send and receive e-mails, and finally print a document after the attendance of the DLP training. The data generated ascertained whether the respondents who attended the DLP training coached their colleagues who had no prior skills. The study noted that the need for computer training among the teachers was too demanding and there was a reason for teachers to learn how to use computers by experimenting with them (Tilya, 2007). The e-learning competencies for teachers required tailored courses on the technical use of computers and other e-learning tools (Ouma et al., 2013). The competencies of the respondents were assessed using questionnaires and interview schedules. 
Table 4. Teachers' computer capacity

\section{Code Operation}

Mean

C17 I can rotate an image

C18 I can create a new document using Microsoft Word

C19 I can create a new document using Microsoft Excel

C20 I can draw and label diagrams using computers

C21 I can use PowerPoint to present my lesson

C22 I can save contents to an external disk

C23 I can animate using computers

C24 I can use a browser such as Mozilla or Explorer to navigate World Wide

C25 I know how to send and receive email messages

C26 I can print a document

$$
n=353
$$

From Table 4, it is evident that teachers were less proficient in rotating an image $\left(\mathrm{M}_{\mathrm{elr}}=3.41>\mathrm{M}_{\mathrm{C} 17}=2.84\right)$, creating a new document using Microsoft Word ( $\mathrm{M}_{\mathrm{elr}}=3.14>\mathrm{M}_{\mathrm{C} 18}=3.03$ ), creating a new document using Microsoft Excel $\left(\mathrm{M}_{\mathrm{elr}}=3.41>\mathrm{M}_{\mathrm{C} 19}=2.88\right)$, drawing and labelling diagrams using computers $\left(\mathrm{M}_{\mathrm{elr}}=3.41>\mathrm{M}_{\mathrm{C} 20}=2.60\right)$, using PowerPoint to present lesson $\left(\mathrm{M}_{\mathrm{elr}}=3.41>\mathrm{M}_{\mathrm{C} 21}=2.67\right)$, saving contents to an external disk (flash disk) $\left(\mathrm{M}_{\mathrm{elr}}=3.14>\mathrm{M}_{\mathrm{C} 22}=2.88\right)$, animating using a computer $\left(\mathrm{M}_{\mathrm{elr}}=3.41>\mathrm{M}_{\mathrm{C} 23}=2.43\right)$, using browsers such as Mozilla or Explorer to navigate the World Wide Web $\left(\mathrm{M}_{\mathrm{elr}}=3.41>\mathrm{M}_{\mathrm{c} 24}=2.67\right)$, sending and receiving email messages $\left(\mathrm{M}_{\mathrm{elr}}=3.41>\mathrm{M}_{\mathrm{C} 25}=2.92\right)$ and printing a document $\left(\mathrm{M}_{\mathrm{elr}}=3.41>\mathrm{M}_{\mathrm{C} 26}=3.03\right)$. When the general mean (2.76) for all areas of ICT skills were measured against the set e-learning readiness scale of 3.41 (Aydin \& Tasci, 2005), it indicated that teachers' computer skills were low and needed much improvement for them to be able to use information technology effectively for teaching.

c) Sample DLP trained teachers in public primary schools in Homa Bay County

The findings showed that $216(61.2 \%)$ sample teachers, who were the majority, had not been offered the DLP training by the government in Homa Bay County. The study also showed that the government had trained 109 (30.9\%) sample teachers, while the remaining 28 (7.9\%) sample teachers failed to declare their position as either trained or untrained by the government as shown in Figure 3. 


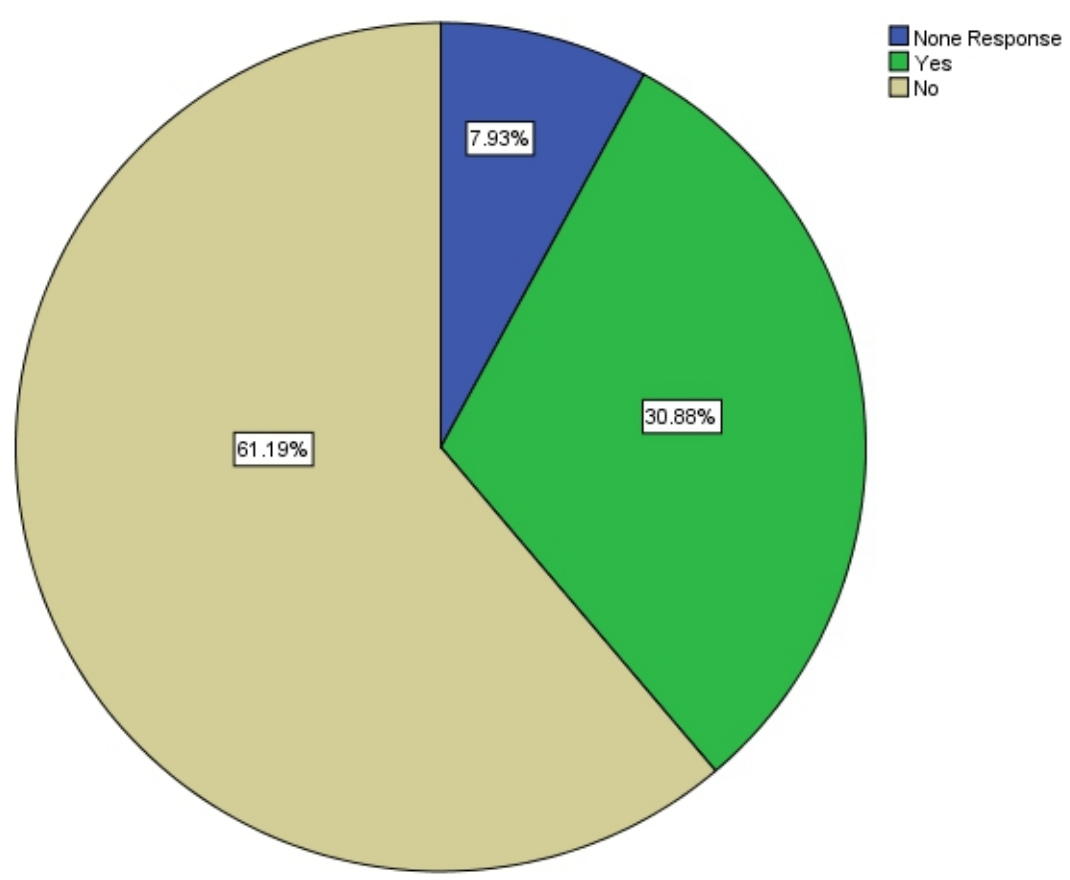

Figure 3. Sample DLP trained teachers in public primary schools in Homa Bay County

d) Number of sampled teachers trained on DLP by the government per sub-county

To establish the levels of teacher training based on each sub-county of Homa Bay. It was revealed that out of the sample size of 82 teachers in Homa Bay Sub-County only $31(37.5 \%)$ had been trained on DLP. In the Sub-County of Mbita, $21(52.5 \%)$ of the sampled teachers had been trained on DLP. Rachuonyo North Sub-County had only 11 (16.9\%) out of 65 teachers of the sample teachers who had attended DLP training. On the other hand, Rachuonyo South Sub-County registered 21 (38.8\%) sample teachers completed training by the government on DLP. In Suba Sub-County, the number of sample teachers who had received DLP training was equally low standing at $10(30.3 \%)$. Fifteen $(22.4 \%)$ of the sample teachers in Ndhiwa SubCounty had been trained by the government on DLP. It was concluded that apart from Mbita Sub-County that registered more than half the number of sample teachers having been trained on DLP, the rest of the sub-counties of Homa Bay County registered low percentages of sample teachers trained on DLP. Table 5 shows these results. 
Table 5. Number of sample teachers trained on DLP by the government per sub-county

\begin{tabular}{lllll}
\hline Sub-County & $\begin{array}{l}\text { Number } \\
\text { trained } \\
\%\end{array}$ & $\begin{array}{l}\text { Number } \\
\text { untrained } \\
\%\end{array}$ & $\begin{array}{l}\text { Non } \\
\text { Response } \\
\%\end{array}$ & $\begin{array}{l}\text { Total } \\
\%\end{array}$ \\
\hline Homa Bay & $31(37.8 \%)$ & $39(46.7 \%)$ & $12(14.6 \%)$ & $82(100.0 \%)$ \\
Mbita & $21(52.5 \%)$ & $19(47.5 \%)$ & $0(0.0 \%)$ & $40(100.0 \%)$ \\
R. North & $11(16.9 \%)$ & $48(73.8 \%)$ & $6(9.2 \%)$ & $65(100.0 \%)$ \\
R. South & $21(31.8 \%)$ & $38(57.6 \%)$ & $7(10.6 \%)$ & $66(100.0 \%)$ \\
Suba & $10(30.3 \%)$ & $20(60.6 \%)$ & $3(9.1 \%)$ & $33(100.0 \%)$ \\
Ndhiwa & $15(22.4 \%)$ & $52(77.6 \%)$ & $0(0.0 \%)$ & $67(100.0 \%)$ \\
Total & $109(30.9 \%)$ & $216(61.2 \%)$ & $28(7.9 \%)$ & $353(100.0 \%)$ \\
\hline & & $n=353$ &
\end{tabular}

To establish the levels of teacher training based on each sub-county of Homa Bay, it was revealed that out of the sample size of 82 teachers in Homa Bay Sub-County only 31 (37.5\%) had been trained on DLP. In the Sub-County of Mbita, 21 (52.5\%) sample teachers completed training on DLP. Rachuonyo North Sub-County had only 11 (16.9\%) out of 65 teachers of the sample teachers who had attended DLP training. On the other hand, Rachuonyo South Sub-County registered 21 (38.8\%) sampled teachers who had been trained by the government on DLP. In Suba Sub-County, the number of sample teachers who had received DLP training was equally low standing at $10(30.3 \%)$. Fifteen (22.4\%) of the sample teachers in Ndhiwa Sub-County had been trained by the government on DLP. It was concluded that apart from Mbita Sub-County that registered more than half the number of sampled teachers having been trained on DLP, the rest of the sub-counties of Homa Bay County registered low percentages of sample teachers trained on DLP.

e) Number of teachers who were trained by DLP trained teachers per school

The teachers and head teachers who were trained on DLP were expected to train other teachers in their respective schools. Table 6 and Figure 4 displays the number of teachers mentioned by sampled head teachers who had received DLP training by their colleagues in schools. 
Table 6. Number of teachers who were trained by DLP trained teachers per sampled school

\begin{tabular}{|c|c|c|}
\hline $\begin{array}{lll}\text { Number of } & \text { teachers } \\
\text { trained by } & \text { DLP } \\
\text { per school } & & \\
\text { peachers }\end{array}$ & Number of schools & Percent \\
\hline 0 & 35 & 44.3 \\
\hline 1 & 3 & 3.8 \\
\hline 2 & 20 & 25.3 \\
\hline 3 & 7 & 8.9 \\
\hline 4 & 9 & 11.4 \\
\hline 5 & 0 & 0.0 \\
\hline 6 & 2 & 2.5 \\
\hline 7 & 1 & 1.3 \\
\hline 8 & 1 & 1.3 \\
\hline 9 & 0 & 0.0 \\
\hline 10 & 1 & 1.3 \\
\hline
\end{tabular}

The study revealed that 35 (44.3\%) sample schools had no teacher trained in their respective schools after the DLP training. Three (3.8\%) sample schools had one teacher trained, 20 (25.3\%) sample schools had 2 teachers trained each, 7 (8.9\%) sample schools claimed to have trained 3 teachers, 9 (11.4\%) sample schools trained 4 teachers, $2(2.5 \%)$ sample schools had 6 teachers trained and the remaining 3 sample schools each (1.3\%) had 7, 8, and 10 teachers trained on DLP respectively. The findings were presented in Table 6. The data from $12(100 \%)$ sampled teachers who were interviewed also showed that teachers' computer skills were still low and needed to be boosted so as to make teachers more comfortable with technology in the classroom. Figure 4 shows more results. 


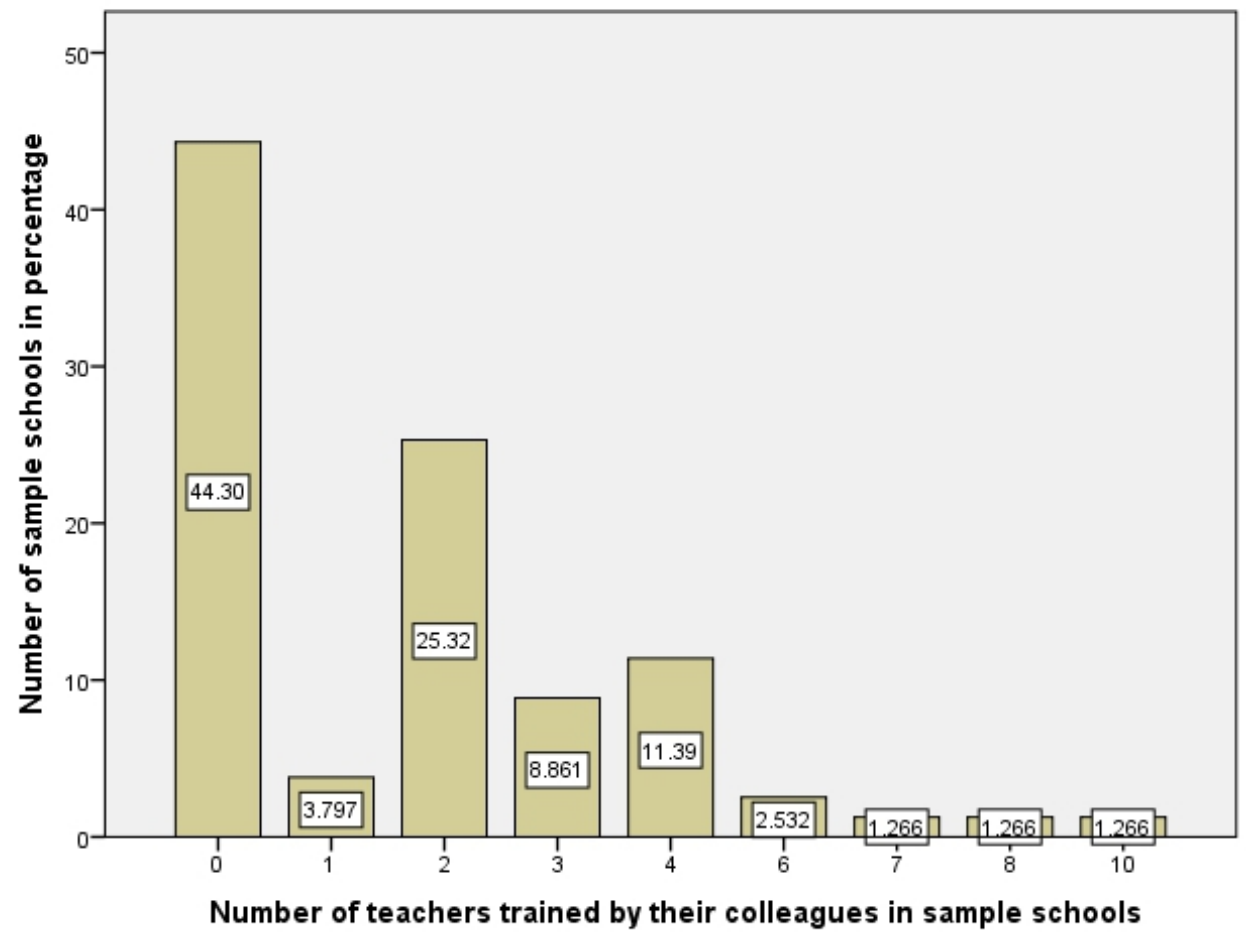

Figure 4. Number of teachers trained by their colleagues in sampled schools

\subsubsection{Discussion}

Computer training for the teaching staff was a very critical area of concern for the Digital Literacy Programme (DLP) in Kenya because teachers were at the center stage of DLP implementation. Teachers were the instructors in schools and their main mission was to integrate technology in schools by introducing DLP devices and assisting learners to adopt them as tools of learning. In support, the European Commission (2011) regarded teachers as key individuals charged with the responsibility of helping students develop ICT skills in the classrooms. Therefore, teachers' computer skills needed to be thoroughly built so that their facilitation role in and out of the classroom could be effective (Hernandez, 2017).

The findings of this research showed that despite the government's commitment in the rollout of ICT literacy in different learning institutions in Kenya, the general teachers' computer skills were low and could not support any fast-moving information technology system. The study, however, noted that low teachers' computer skills did not mean that nothing had been done in Kenya in terms of commitment and awareness of the computer as a tool of learning. The research findings showed that computer training in various learning institutions in Kenya started long before the idea of DLP in Kenyan 
primary schools was mooted (Kenya. MoE, 2006). To prove this, the study showed that $199(56.4 \%)$ sample teachers, who were the majority of the respondents, had attended computer training at various institutions and not specifically the tailored DLP training that was offered by the Government of Kenya. The training period for these teachers lasted for more than one month as opposed to the five-day DLP training. DLP training, on the other hand, was launched in 2015 (Republic of Kenya, 2015) and notably, 109 (30.9\%) sample teachers benefited from this program in Homa Bay County. The training required no entry level for computer training for trainee teachers. The study observed that with the introduction of such training, a lot of emphasis needed to be put in computer training because the percentage, $(56.4 \%)$, of sampled teachers, who were computer literate at the time of this study, was higher than the percentage, $(30.9 \%)$, of sampled DLP-trained teachers in Homa Bay County. It was a clear indication from this study that the pace of DLP training was low and demanded quick remedy. The findings were in concurrence with those of the teachers who were interviewed that indicated that teachers' computer skills were low and needed to be improved before the launch of DLP in Kenyan schools.

The study also showed that such DLP training was necessary to advance laptop computer integration in its schools. In support, the Ministry of Education in Kenya was committed to facilitating ICT as a tool for education in all institutions of learning in Kenya by use of appropriate ICT infrastructures, teachers' competencies, and policies (Kenya. MoE, 2006, p.9). The study concluded that even though the 5-day DLP training offered to teachers by the government in 2015 was believed to be too short, it helped a lot to familiarize teachers with the much-needed educational software (European Commission, 2001, p.27). In fact, it was important for some of the teachers who had the opportunity to touch and feel computers for the first time in their lives. In concurrence, the European Commission (2001) suggested that training should be done in phases and the very first one should only be a key opener in the world of ICT by exposing trainees to different ICT tools before actual training begins. In this light, the study considered the Kenyan 5-day DLP training as a familiarizing phase of technology adoption awaiting actual training. In fact, many respondents were not comfortable with the five-day DLP training claiming that the training period was not commensurate with the task that teachers were expected to perform in classrooms with DLP devices under their control.

The expectation of the government was that only a few teachers would be trained on DLP and these skilled teachers would, in turn, coach their colleagues. The research findings showed that 35 (44.3\%) of the sample public primary schools in Homa Bay County had no teacher trained by their colleagues on DLP. The reasons that were cited by head teachers of sample 
schools whose DLP-trained teachers failed to train other staff members were the absence of DLP devices in their respective schools for training other teachers and the fact that the five-day DLP training conducted by the Government of Kenya did not impact enough skills that could be shared with other teachers in schools. The European Commission (2001) suggested that for effective ICT integration, ICT trained teachers needed to be motivated after any meaningful training by either offering them computers free as was witnessed in Sweden or subsidizing the cost of computers so that they are affordable to trainees as was done in the United Kingdom. In support, Tilya (2007) observed that teachers from different schools who had gone through the training process and had hands-on ICT experience helped their schools to understand the contribution of ICT to learning and could use different learning approaches in education.

The study also showed that sub-counties of Homa Bay were not treated equally in terms of DLP training. There was a lack of equity. The researchers noted that some sub-counties such as Ndhiwa in particular recorded as low as $15(22.4 \%)$ for DLP training for sample teachers. It was not clear to the researchers why such disparity in DLP training occurred because DLP training was a national affair and sponsored by the government. More so, all counties in Kenya had all the relevant ministries and staff for DLP. The other subcounties also equally registered varied numbers of sample teachers trained for DLP but still, the numbers were low and not uniform. Therefore, for successful implementation of DLP, the study suggested that the government needed to improve supervision to schools and conduct a thorough audit of DLP to ensure that the starting point was same for all schools in Kenya. The findings, indeed, contradicted the Kenyan Government report which indicated that nearly all public primary schools in all regions of the Republic of Kenya had at least a head teacher and two other teachers trained on DLP by 2015 (Republic of Kenya, 2015).

\section{Conclusion and Recommendations}

In conclusion, both qualitative and quantitative data were in concurrence that teachers' strong foundation in computer skills was necessary before the launch, during the launch and after the launch of DLP in Kenya. This is because the teachers, who were the respondents for this study, were in agreement that the expected level of computer training had not been met by the government DLP training. In addition to inadequate DLP training, the study showed that only a smaller percentage of teachers $(30.9 \%)$ had been trained on DLP in Homa Bay County. The study, therefore, concluded that based on the standard e-learning readiness scale of 3.41 which was the expected e-learning readiness level that is safe for the launch of DLP (Aydin \& Tasci, 2005), a lot was still expected to be done for public primary schools 
and teachers to improve the level of readiness for DLP in Kenya. This could be achieved by ensuring that proper structures for training are put in place and providing all schools with DLP devices to enable teachers to practice with the devices in the process of teaching and learning in their schools. The study recommended that the government needed to take charge of DLP by close supervision of the integration process and at least reward teachers who were teaching using DLP devices.

\section{References:}

1. Aydin, C. H., \& Tasci, D. (2005). Measuring readiness for e-learning: Reflections from an emerging country. Educational Technology \& Society, 8 (4), 244-257.

2. Creswell, J.W. (2011). Research design. Qualitative, quantitative, and mixed methods approaches $\left(3^{\text {rd }}\right.$ Ed.). Boston: Pearson Education, Inc.

3. Creswell, J.W. (2012). Educational research. planning, conducting, and evaluating quantitative and qualitative research ( $4^{\text {th }} \mathrm{Ed}$.).Boston: Pearson Education, Inc.

4. European Commission (2001). Information and communication technology in European education systems. Brussels: Eurydice European Unit.

5. European Commission (2011). Key data on learning and innovation through ICT at school in Europe. Brussels: Education, Audiovisual and Culture Executive Agency. Retrieved from:

6. https://www.cseeetuce.org/images/attachments/ictkeydata_on_learnin g_and_innovation_through_ict_2011_summary.pdf

7. Fraenkel, J.R. \& Wallen, N.E. (2009). Design and evaluate research in education ( $7^{\text {th }}$ Ed.). New York: McGraw-Hill Higher Education.

8. Hennessy, S., Harrison, D., Ang'odi, E.K., Nemalefe, S., Naseem, A., \& Wamakote, L. (2010). Developing the use of information and communication technology to enhance teaching and learning in east African schools: Review of the literature. Eastern Africa : Centre for Commonwealth Education and Aga Khan University Institute for Educational Development.

9. Hernandez, R.M. (2017). Impact of ICT on education: Challenges and perspectives. A manuscript presented for publication. Retrieved from: http://dx.doi.org/10.20511/pyr2017.v5n1.149

10. Khan, S. H., Hasan, M., \& Clement, C.K. (2012). Barriers to the introduction of ICT into education in developing countries: The example of Bangladesh. International Journal of Instruction, 5(2).Retrieved from: www.e-iji.net

11. Kenya. MoE (2006). National ICT strategy for Education and Training. Nairobi: Ministry of Education 
12. Kisirkoi, F. K. (2015). Integration of ICT in Education in a Secondary School in Kenya: A Case Study. Literacy, Information and Computer Education Journal, 6(2), 1345-1350.

13. Kothari, C.R., \& Garg, G. (2014). Research methodology. Methods and techniques ( $3^{\text {rd }}$ Ed). New Delhi: New Age International Publishers.

14. Mathevula, M. D. \& Uwizeyimana, D. E. (2014).The challenges facing the integration of ICT in teaching and learning activities in South African rural secondary schools. Mediterranean Journal of Social Sciences, 5 (20).

15. Meenakshi, K. (2013). Importance of ICT in education. Journal of Research and Method in Education (IOSRJRME)1(4),3-8.

16. Mingaine, L. (2013). Skill challenges in adoption and use of ICT in public secondary schools, Kenya. International Journal of Humanities and Social Science, 3 (13).

17. Mndzebele, N. (2013). Teachers readiness in using ICT in the classroom: The case of a developing country. International Journal of Information and Education Technology, 3(4). Nyagowa, H.O.,Ocholla,D.N.,\& Mutula,S.M.(2012).Evaluation of success of NEPAD's pilot e-schools in Kenya: An overview. Unpublished manuscript. Retrieved from: ttp://www.lis.uzulu.ac.za/research/2012/Nyagowa\%20and\%20Ocholl a\%20and\%20Mutula\%20SCECSAL\%202012,KPUC\&UZ\&UKZN\% 203.pdf

18. Ouma, G.,O.,Awuor ,F.M.,\& Kyambo, B.(2013).E-learning readiness in public secondary schools in Kenya. European Journal of Open, Distance and e-Learning, 16 (2).

19. Republic of Kenya (2015). Digital Literacy Program [press release]. Retrieved from: Information, Communication and Technology Authority of Kenya website: http://www.icta.go.ke/downloads/digital_literacy_program_launch.pd $\mathrm{f}$

20. Sharples, T. \& Moldéus, K. (2014). Ready or not, here ICT comes: A case study one-readiness and governance in Kenya 's laptop computers project (Unpublished masters theseis). Lund University, Sweden.

21. South Africa. DoE (2003) .Draft White Paper on e-education :Transforming learning and teaching through ICT. South African Government website: https://www.gov.za/sites/default/files/eeducation_1.pdf

22. Tella, A., Toyobo, O. M., Adika, L. O.,\& Adeyinka, A. A. (2007). An assessment of secondary school teachers' uses of ICT'S: Implications for further development of ICT'S use in Nigerian secondary schools. 
The Turkish Online Journal of Educational Technology - TOJET, 6, (3). Retrieved from: www.tojet.net/articles/v6i3/631.pdf

23. Tilya, F. (2007).ICT in education in Tanzania. Lessons and experiences from IICD-supported projects. Retrieved from infoDev website:

https://www.infodev.org/infodevfiles/resource/InfodevDocuments_432.pdf

24. UNESCO Institute for Statistics (2012).ICT in education in Latin America and the Caribbean. A regional analysis of ICT integration and e-readiness. Retrieved from UNESCO website: http://uis.unesco.org/sites/default/files/documents/ict-in-education-inlatin-america-and-the-caribbean-a-regional-analysis-of-ictintegration-and-e-readiness-en_0.pdf. 